\title{
Youth Pathways in Articulated Postsecondary Systems: Enrolment and Completion Patterns of Urban Young Women and Men*
}

\section{LESLEY ANDRES \& HARVEY KRAHN}

The University of British Columbia \& University of Alberta

\begin{abstract}
This paper uses panel survey data to document the postsecondary educational activity of high school graduates in Edmonton and Vancouver over a five-year period. It enquires whether, in "articulated" postsecondary systems offering a range of institutional choices and a variety of transfer options, large class and gender differences in participation and completion continue to be observed. The results reveal that even in systems explicitly designed to improve access to and encourage completion of postsecondary programs, family background continues to strongly influence postsecondary outcomes. In both cities, social class advantages appear to be passed from one generation to the next, to a large extent, through the high school tracking system, since high school academic program is a strong predictor of postsecondary participation and completion. Gender also continues to matter, but in more subtle ways than in the past.

* The authors would like to thank several anonymous reviewers for this journal for their helpful comments on an earlier draft of this paper. We wish to acknowledge the support received from the Social Science and Humanities Research Council of Canada in the form of a strategic research grant in the theme area of Education and Work in a Changing Society. The grant has enabled the co-investigators to develop a collaborative network in order to compare and contrast their longitudinal data sets. Also, we acknowledge the support of the Social Science and Humanities Research Council of Canada, the B.C. Council on Admissions and Transfer, and the Alberta government in funding our individual longitudinal research projects.
\end{abstract}


Young women and men are equally likely to participate in the postsecondary system, but they continue to make different types of educational choices that, in turn, determine participation patterns and the acquisition of postsecondary credentials. The paper concludes by discussing the educational policy implications of these findings.

\section{RÉSUMÉ}

Le présent article utilise des données recueillies lors d'une enquête échelonnée dans le temps, pour documenter l'activité en éducation postsecondaire des détenteurs d'un diplôme de fin d'études secondaires à Edmonton et à Vancouver, au cours d'une période de cinq ans. La question était de savoir si, dans des systèmes postsecondaires «articulés» qui offrent toute une série de choix et de possibilités de transfert, des différences marquées selon la classe et le sexe continuent à s'observer. Les résultats indiquent que, même dans des systèmes conçus spécifiquement pour améliorer l'accès à des études postsecondaire et l'achèvement de ces études, le milieu familial continue à influencer fortement les résultats après le secondaire. Dans les deux villes, les avantages de classe sociale semblent, en grande partie, se transmettre d'une génération à une autre, par l'intermédiaire du suivi au niveau du deuxième cycle de secondaire, vu que le programme d'études adopté dans le deuxième cycle de secondaire est un fort indicateur quand il s'agit d'entamer et de mener à bien des études postsecondaire. L'appartenance à un sexe continue également à jouer un rôle, mais de façon plus subtile que par le passé. Jeunes hommes et jeunes filles sont aussi susceptibles les uns que les autres d'entrer dans le système postsecondaire, mais ils continuent à effectuer des choix différents, qui influent en aval sur les schémas de participation et sur l'acquisition de titres après le secondaire. L'article s'achève sur une discussion des implications de ces constats au niveau de la politique en matière d'éducation.

\section{INTRODUCTION}

The principle of equality of opportunity of access has influenced the dramatic expansion of postsecondary education in Canada in the second half of the twentieth century. The equality of opportunity perspective argues that educational barriers based on ascriptive characteristics or "accidents of birth" interfere with the goal of higher education being 
available on an equitable basis to all Canadians who are qualified and want to study (Department of the Secretary of State, 1988; Report of the Provincial Access Committee, 1988; Report of the Standing Senate Committee on National Finance, 1987).

During the past several decades, expansion of the Canadian postsecondary system has meant that larger proportions of qualified youth have been able to attend community college or university. Even so, several studies conducted in the past two decades demonstrate persistent social class (as measured by parental educational and income levels) and gender differences in postsecondary participation rates in general, and university participation rates in particular (Anisef, 1985; de Broucker \& Lavallée, 1998; Fortin, 1987; Guppy, 1984; Report of the Royal Commission on the Economic Union and Development Prospects of Canada, 1983).

For example, a joint study by Statistics Canada and the Department of the Secretary of State (Porter \& Jasmin, 1987) demonstrated that: 1) undergraduate university education continued to be dominated by children of upper-middle and upper class parents; 2) parents of community college students tended to have lower levels of education; and 3) the class bias was declining very slowly. Guppy and Pendakur (1989) found that a decline in the effects of gender on postsecondary participation exacerbated the impact of family origin. That is, compared to their male counterparts, women participating in postsecondary education in the 1980 s were more likely to have better educated parents. Some of the change was attributed to growing female participation in non-university education. Other studies revealed that although female enrolment in university increased dramatically after 1970 , substantial gender differences by program of study at the undergraduate level and in enrolment in graduate education remained (Andres \& Guppy, 1991). It appeared, as Alexander, Pallas and Holupka (1987) noted, that "traditional patterns of educational stratification are highly resilient" (p. 181).

All of these studies relied on data from national samples which are unable to describe the patterns of enrolment and completion within particular provincial postsecondary systems which vary considerably across Canada (Jones, 1997). The structure of each system and its articulation with the secondary system determines the way in which students access and progress through it. In the Report of the Committee to Examine Participation Trends of Alberta postsecondary Students (Alberta Advanced Education, 1984), it was argued that within a differentiated 
system of postsecondary education, equality of opportunity of access should mean that different opportunities are available to different students; that is, the postsecondary system should offer different types and levels of education with varying starting points and outcomes. The report states:

this orientation presupposes that Canadian society is pluralistic and heterogeneous and that its citizens have a diversity of learning needs. A pluralistic society is well served by a pluralistic education system. There appears to be no intrinsic merit in seeking a singular pattern - namely that of university attendance. In fact, this pattern of thought could prove detrimental to both potential students and the country's economic development. (Alberta Advanced Education, 1984, p. 20)

Today, in all but three provinces "binary systems" of postsecondary education are in place in which university and non-university education do not overlap. For example, universities and colleges in Ontario are described as "two distinct types of postsecondary [institution], each targeted towards different goals. Their roles are different, but complementary" (Ministry of Education and Training, 1996). However, British Columbia, Alberta, and Quebecl have developed "ternary" or "articulated systems" where formal arrangements permit students with appropriate prerequisites earned at community colleges to transfer to university. From an equality of opportunity of access perspective, community colleges are intended to play a central role.

Proponents of such "articulated" postsecondary systems claim that by offering university-equivalent courses along with lower tuition fees, flexible admission requirements, and programs located within commuting distance, community colleges are "democratizing" in that they provide opportunities for individuals with less privileged backgrounds to pursue postsecondary studies, including university degree completion (Alberta Advanced Education, 1984; Dennison \& Gallagher, 1986; Fortin, 1987). Community colleges within articulated systems are thus seen to offer "new avenues of opportunity for the previously disenfranchised" (Dennison \& Gallagher, 1986, p. 162).

In terms of life chances, however, critics allege that attendance at a community college is far from democratizing (Karabel, 1986; Pincus, 1986). From a class-reproduction perspective, community colleges are seen as second-best institutions where the aspirations of minority and 
disadvantaged youth are "cooled out" (Clark, 1960). Anisef (1985) argues that Canada's "pluralistic education system" camouflages the hierarchical relationships that exist among postsecondary institutions and serves to obscure the class-based choices students make after leaving high school. As Karabel (1986) observes:

far from embodying the democratization of higher education and a redistribution of opportunity in the wider society, the expansion of the community college instead heralded the arrival in higher education of a form of class-linked tracking that served to reproduce existing social relations. To be sure, some individuals who would otherwise have been excluded from higher education have used the community college as a platform for upward mobility; yet, ... the overall impact of the community college has been to accentuate rather than reduce prevailing patterns of social and class inequality. (Karabel, 1986, p. 18)

Moreover, numerous studies reveal that transfer rates from community colleges to universities remain low and that the probability of degree completion is generally superior when postsecondary education commences in a degree-granting institution (Alba \& Lavin, 1981; Anderson, 1984; Astin, 1982; Medsker \& Tillery, 1971; Velez, 1985). Tinto (1975) found that the presence of a public two-year college in a community acted as a redistributive mechanism and did less to increase rates of college attendance than to alter the type of postsecondary institution attended. He found the substitution of a public two-year college for a four-year college (i.e., university) to be inversely related to socio-economic status and not related to academic ability. Brint and Karabel (1989) maintain that a "diversion effect" accompanies the "democratization effect" of community colleges.

\section{PURPOSE OF THE STUDY}

As already noted, the British Columbia and Alberta postsecondary systems were designed as articulated systems, so as to offer potential students a range of postsecondary options, including transfer between institutions. The purpose of this paper is to profile the postsecondary educational activity of cohorts of Vancouver and Edmonton high school graduates over a five-year span immediately after graduation. As such, 
our study design involves examining two systems explicitly designed to enhance access to postsecondary education in Canada and based on the ideological notion of seamlessness throughout the system. Our focus on youth living in large metropolitan areas eliminates the influence of rural residence which is often a serious barrier to postsecondary participation and completion (Andres \& Looker, 1997; O'Neill, 1981). Because both cities offer a wide range of postsecondary institutions, high school graduates should be able to "choose" the postsecondary route most suited to their aspirations and achievement levels. Hence, if we were to find evidence of limited impact of family background (socio-economic status), we should find it in these two cities.

Although we expect similar patterns of postsecondary educational activity among youth in the two cities, we recognize that some differences are likely to appear, either because of differing labour market conditions (see Appendix), or because of variations in the educational systems. Thus, to contextualize this study, we begin by providing an overview of each provincial postsecondary system. Then, using panel data on youth who graduated from high school in 1985 (Edmonton) and 1988 (Vancouver), we examine participation rates within the various types of postsecondary institutions in the two cities, and completion rates by institution of entry. Unlike previous cross-sectional studies, our longitudinal data allow us to focus on movement through the system. By discussing the participation and completion rates of youth from middleclass and less affluent families we can better determine whether articulated systems designed to reduce class inequalities have been effective. Similarly, by highlighting the postsecondary educational experiences of young women and men in a range of different educational institutions, we can determine whether gender differences in postsecondary educational activity have really disappeared. Finally, by tracking students out of high school and through the postsecondary system, we can gain a better understanding of how program choices in high school, frequently influenced by family background, may have an impact on subsequent postsecondary choices and success.

\section{THE ALBERTA POSTSECONDARY SYSTEM}

By 1945, Alberta already had a reasonable number of postsecondary institutions, including the University of Alberta (in Edmonton), an Institute of Technology and Art (in Calgary), the Banff School of Fine 
Arts, two agricultural colleges, two Normal Schools training teachers, and several private colleges. But the system expanded rapidly in the decades following World War II as new demands were placed on it, first by returning veterans, and later by rising birth rates, increased immigration, and oil-industry driven economic growth. These social and economic forces coincided with the growing recognition that, in an increasingly urbanized economy, education was a key "path to a good life" (Andrews, Holdaway, \& Mowat, 1997, p. 60).

The university system grew to include the University of Calgary and the University of Lethbridge (both established in the late 1960s), and Athabasca University, a "distance learning" institution established in the early 1970s. Alberta was also home to the first Canadian "community college" - the Lethbridge Junior College, founded in 1957. From its inception, this college offered university-equivalent courses that were recognized by the University of Alberta (Berghofer \& Vladicka, 1980). Legislation in 1958 (the Public Junior Colleges Act) specified a dual role for all Alberta colleges; hence, each institution within the public colleges system offered university transfer and non-university courses (Andrews, Holdaway, \& Mowat, 1997; Berghofer \& Vladicka, 1980). By 1975, seven public colleges existed; some (e.g., Red Deer College and Grant MacEwan College in Edmonton) were set up as new institutions and others (e.g., Mount Royal College in Calgary) grew out of existing private institutions. These colleges varied in the degree to which they focussed on university-equivalent and more comprehensive course offerings.

By the early 1970s, transfer of students between institutions had become a central issue, with complaints from college personnel about the restrictive nature of transfer policies. In 1971, the Mowat Committee was set up to examine the issue and, following a long debate, in 1974 the Alberta Council on Admissions and Transfer was established. Its mandate was to develop "policies, guidelines, and procedures designed to facilitate transfer arrangements among postsecondary institutions" (Alberta Council on Admissions and Transfer, 1994, p. 1). This council, with its annually published Alberta Transfer Guide, served as a model for articulated postsecondary systems elsewhere in Canada.

In anticipation of increased demand for individuals with technical skills, other postsecondary institutions were added to the Alberta system. In 1960, the Northern Alberta Institute of Technology (NAIT) was established in Edmonton and the Provincial Institute of Technology and Art 
(in Calgary) was renamed the Southern Alberta Institute of Technology (SAIT). To further enhance the employability skills of Albertans, Alberta Vocational Centres (subsequently renamed Alberta Vocational Colleges) were also set up in several locations. Today, the Alberta postsecondary system consists of four universities, four degree granting private colleges, eleven community colleges, two technical institutes, four vocational colleges, the Banff Centre for Continuing Education, three hospital-based schools of nursing, and numerous other private training institutions (Andrews, Holdaway, \& Mowat, 1997).

In 1985 , when the Edmonton panel study began, local youth could access a wide range of postsecondary institutions within commuting range, including the University of Alberta, Grant MacEwan Community College, the Northern Alberta Institute of Technology (NAIT), Alberta College, Concordia College, King's College, and AVC-Edmonton. Formalized arrangements allowed for transfer of credit for specified courses from Grant MacEwan College to the University of Alberta (in the years following, the transfer arrangements were broadened to include a number of specified programs as well as designated courses). The University of Alberta was the only Edmonton institution that could grant degrees. By 1992, however, both Concordia College and The King's University College had received the right to award undergraduate degrees in specified program areas (Andrews, Holdaway, \& Mowat, 1997).2

\section{THE BRITISH COLUMBIA POSTSECONDARY SYSTEM}

The major catalyst in the development of today's higher education system in British Columbia was the Macdonald Report, Higher Education in British Columbia, published in 1962. Authored by the President of the University of British Columbia, John Macdonald, it laid the foundation for an entirely new system of higher education in the province (Andres \& Dawson, 1998). ${ }^{3}$

According to Macdonald, one key requirement for the achievement of excellence in an expanded and extended higher education system was diversification of both the kinds of educational opportunities available and the places where education could be obtained. In order to meet the needs of a rapidly changing society and workforce, many kinds of educational programs were required beyond the traditional offerings of the university. Underlying the report was a vision of education as a 
democratizing agent that would provide new avenues of opportunity for those previously unable to gain access to the postsecondary system.

The recommendations of the Macdonald Report included the establishment of two more universities in the major urban centres, and the creation of a number of two-year community colleges in various regions throughout the province. The universities would continue to provide degrees in the liberal arts, the sciences, the professions, and graduate studies. The objectives of new community colleges would include one or more of the following:

(a) two-year academic programmes for students who will either transfer to degree-granting institutions or will complete their formal education at this level; (b) technological and semiprofessional courses designed for students who want formal education beyond high school but who do no plan to complete the requirements for a degree; adult education, including reeducation to meet the changing demands of technical and semi-professional occupations. (Macdonald, 1962, p. 51)

This diversification of institutional roles reflected Macdonald's belief that "to insist that each [institution] . . . train young men and women in the same way is to confuse the aims and methods of education" (p. 54). With regard to the implications for students wanting to transfer from one institution to another in such a diversified and autonomous system, Macdonald recommended a system of parallel institutions and programs that were not necessarily identical.

The Macdonald Report was received enthusiastically. It was a time when there was widespread political and public confidence that education could create a more democratic society. Over the next ten years, two new universities were created (Simon Fraser University was completely new while the University of Victoria grew out of what was once Victoria College) along with nine community colleges. By 1975, the number of community colleges had increased to fourteen.

Community colleges, with their greater predisposition to curricular experimentation, closer association with the communities, and fewer "preconceived notions about what an institution of higher learning should be" (Jeffels, 1972), faced ongoing challenges - most frequently from within the higher education community itself. Despite the ideal of diversified and equal educational opportunities advanced in the Macdonald Report, as the new kid on the institutional block colleges 
had to struggle to identify themselves as separate from but equal to universities. They faced persistent charges that they provided a second-rate education - that they were potential "havens for second class citizens whose academic achievements were insufficient to allow them entrance to the universities" (Dennison \& Jones, 1970).

These tensions aside, by 1988 the postsecondary system in British Columbia was described as a "diversified and well-developed structure for advanced education and job training" (Report of the Provincial Access Committee, 1988, p. 3). The system had expanded to include three public universities, one private university, fifteen community colleges, four public institutes, an Open Learning University and an Open Learning College, as well as many private colleges and trade schools. The system served 116,500 full-time and part-time students annually in non-vocational education ${ }^{4}$ and over 12,000 students in full-time vocational programs (Department of the Secretary of State of Canada, 1990; Ministry of Advanced Education and Job Training, 1988).

However, by the mid-1980s, issues of access to the postsecondary system once again began to plague educators and policy makers. Low participation rates, including the transition of high school graduates to the postsecondary system, prompted the British Columbia Ministry of Advanced Education to adopt some of the recommendations of the Provincial Access Committee (Report of the Provincial Access Committee, 1988). Accordingly, the B.C. postsecondary system expanded once again, and by 1990 included four public universities, one private university, five university colleges, eleven community colleges, four public institutes, an Open University and an Open College, and literally hundreds of private colleges and trade schools.

Hence, B.C. students leaving high school in 1988 were confronted with a postsecondary system that was extensive, highly diversified, and advanced in terms of inter-institutional articulation. For youth graduating from high school in Vancouver in 1988, the local postsecondary system offered a full range of choices. Two public universities (the University of British Columbia and Simon Fraser University), one private university (Trinity Western University), four community colleges (Vancouver Community College, Douglas College, Capilano College and Kwantlen College), four public institutes (BCIT, Justice Institute, Emily Carr, Pacific Marine Training Institute), the Open University and Open College, and a range of private postsecondary institutions were within easy commuting distance of anyone living in Greater Vancouver. 
Comparing the postsecondary options available to Vancouver and Edmonton youth, it is apparent that, in general terms, the two systems were similar. However, Vancouver appeared to offer somewhat greater choice to young people (i.e., two universities and a larger number of community colleges). Consequently, this might lead to some differences between the two cities in terms of the educational activity of youth following high school.

\section{DATA COLLECTION}

This analysis is part of the larger research agenda of a formal network of Canadian researchers studying educational and work transitions. The goals of this network are to: 1) provide a forum for ongoing communication among Canadian researchers who are actively engaged in longitudinal research on the transition of youth to adulthood, and 2) maximize the utility of existing studies through comparative research efforts.

The Edmonton study began in 1985, as part of a three-city study (Edmonton, Toronto, and Sudbury) of school-work transitions. Only Edmonton data are examined in this paper, since this panel study was not continued beyond 1989 in the other two cities, and given our focus on the two similar postsecondary educational systems in Alberta and British Columbia. In this study, we analyze only the information provided by Edmonton students about their educational activity between 1985 and 1990.

A total of 983 Edmonton twelfth-grade students were surveyed, in class, in May and June of 1985. Six schools from the public school system, representing a mix of schools in "middle class" and "working class" neighbourhoods, were purposively chosen for the study. In each school, an attempt was made to survey students in academic and nonacademic (i.e., vocational, technical or business) programs. Across all schools, approximately two-thirds of the sample members were in academic programs.

The baseline sample contained slightly more male $(52 \%)$ than female respondents. The average age of respondents was just over 18 years. Four out of five were born in Canada and one in three (34\%) reported that their mother had completed at least some postsecondary education ( $15 \%$ had a university degree). Almost half (49\%) indicated that their father had completed some postsecondary education ( $26 \%$ had a university degree). Just over three-quarters of the respondents $(79 \%$ of females and $75 \%$ of 
males) reported that they planned to continue their education immediately (i.e., in the fall term) after graduating from high school.

Most of the Edmonton survey participants $(n=894)$ provided their name and address when completing the baseline questionnaire, thus expressing their willingness to be contacted again. Follow-up surveys were completed by mail in 1986, 1987, 1989, and 1992. In each wave of data collection, only those individuals who had responded in the previous wave were contacted. Thus, by 1992, the sample had dropped to 404 respondents (Krahn, \& Mosher, 1992). The implications of this sample attrition are discussed in the Appendix to this paper.

The British Columbia study began four years after the Edmonton study. The primary purpose of the B.C. study was to map postsecondary participation patterns of high school graduates. The first phase of the study consisted of a 1989 postal survey focusing on the educational choices made by a large systematic sample of 1988 high school graduates $(\mathrm{n}=5345)$. The study included postsecondary participants and nonparticipants from all 75 school districts in British Columbia (see Andres, 1995 for a detailed description of the sample). High school and postsecondary records, providing demographic, academic achievement and institutional information, were linked to the questionnaire data. In 1993, a second follow-up of the 1989 study was carried out. Individuals who had completed the first survey were contacted by mail, and a total of 2030 completed the 1993 follow-up survey (see Appendix for an assessment of sample attrition).

Baseline data collected in 1989 indicate that most $(82 \%)$ respondents were 18 years of age. More females $(56 \%)$ than males responded to the initial survey and overall levels of parental education were somewhat higher than those reported by Edmonton students. That is, respondents reported that $49 \%$ of their mothers and $62 \%$ of their fathers had completed some form of postsecondary education. University degree attainment of parents paralleled the Edmonton sample (19\% of mothers and $27 \%$ of fathers had earned a bachelors degree or greater). Two-thirds of respondents graduated from academic programs in high school.

In order to ensure as much comparability as possible with the Edmonton sample, in the British Columbia study only those respondents who lived within easy commuting distance of one of the many postsecondary institutions in Vancouver or the surrounding area were included in the "Vancouver" sample. 5 Thus, the analyses discussed 
below do not address the issue of access to postsecondary institutions among high school graduates in rural areas or smaller communities in the two provinces.

\section{MEASUREMENT}

Our central concerns in this study of recent high school graduates are: a) postsecondary educational participation patterns; and b) postsecondary completion rates. Because of small sample sizes, we cannot distinguish between programs within postsecondary institutions. Instead, for each of the five years of the study, we categorize respondents on the basis of whether they attended universities, vocational/technical schools, or community/university colleges, participated in other postsecondary activities (typically in private institutions that did not provide an accredited degree or diploma), or were non-participants in the postsecondary system. We classify any attendance during the year (i.e., part-time or part-year) as "participation" in the system. ${ }^{6}$ With respect to completion rates, respondents are categorized according to whether they received (by the end of the five year period) a university degree, a technical/vocational school diploma, a community college diploma, or no credential at all, regardless of the type of institution where they began their studies. It is important to distinguish participation in vocational or technical institutions from community college participation. Whereas community colleges in articulated systems offer a full range of programs including university-equivalent study, traditionally postsecondary institutions offering vocational or technical training, with a focus on trades, are more likely to attract working class males. By distinguishing between these types of non-university institutions, we are better able to examine the gendered and class-based nature of participation.

There are many different ways in which we might operationalize family socio-economic background. We have chosen to use parents' education as our indicator, for two reasons. First, in contrast to alternative measures (e.g., income, occupational status), we would expect parents' education, in the form of cultural capital (Bourdieu, 1986) to play a more direct role in determining their children's educational choices. Second, and more pragmatically, the respondents in our study were more likely to have reasonably accurate knowledge of their parents' education. Thus, for the analyses we present below, we categorize subjects into two groups: one or both parents with a university degree; no parent with a degree. 
Gender is our second key independent variable. In addition, we compare the postsecondary participation and completion rates of respondents who completed an "academic" high school program with those who graduated from a more basic or vocational program. In Vancouver, this information was obtained from official school records, while in Edmonton it was self-reported by respondents.

\section{FINDINGS}

\section{Postsecondary Participation Patterns}

In the first table presented, we document the postsecondary activity of Edmonton and Vancouver youth over a five year period following high school. For Edmonton youth, the two most common pathways directly following high school were university entry or non-participation in postsecondary education (Table 1). University participation remained quite constant at 36 to $38 \%$ over the first four years, then dropped to $24 \%$ in year five. The second most common form of postsecondary participation for this group was attendance at vocational or technical institutions. Only 5 to $7 \%$ of Edmonton youth attended community colleges in any given year between 1985 and 1990. Participation at "other" postsecondary institutions is slightly higher; $10 \%$ attended this type of institution directly following high school, and by 1995 the attendance rate was $7 \% .^{7}$ The non-participation rate directly following high school was $34 \%$ and remained constant over the first three years. In years four and five the non-participation rate rose, coinciding with the decline in participation at university and vocational/technical institutions.

Postsecondary participation patterns of Vancouver youth were somewhat different. Forty-one percent entered university directly out of high school. This proportion rose over the first four years, reaching $52 \%$ by 1992-93, and declining slightly by 1993-94. Unlike Edmonton youth, the second most common trajectory was community college participation. Following high school, one third commenced their postsecondary studies at community colleges. This proportion declined over five years, and by 1993-1994, only 13\% remained in community colleges. This differs from the Edmonton participation patterns in that, as community college participation declined, university participation increased, suggesting inter-institutional transfer. Participation at vocational/technical and 
Table 1

Postsecondary Educational Activity Within Five Years of Leaving High School; Edmonton (1985-1990) and Vancouver (1988-1993)

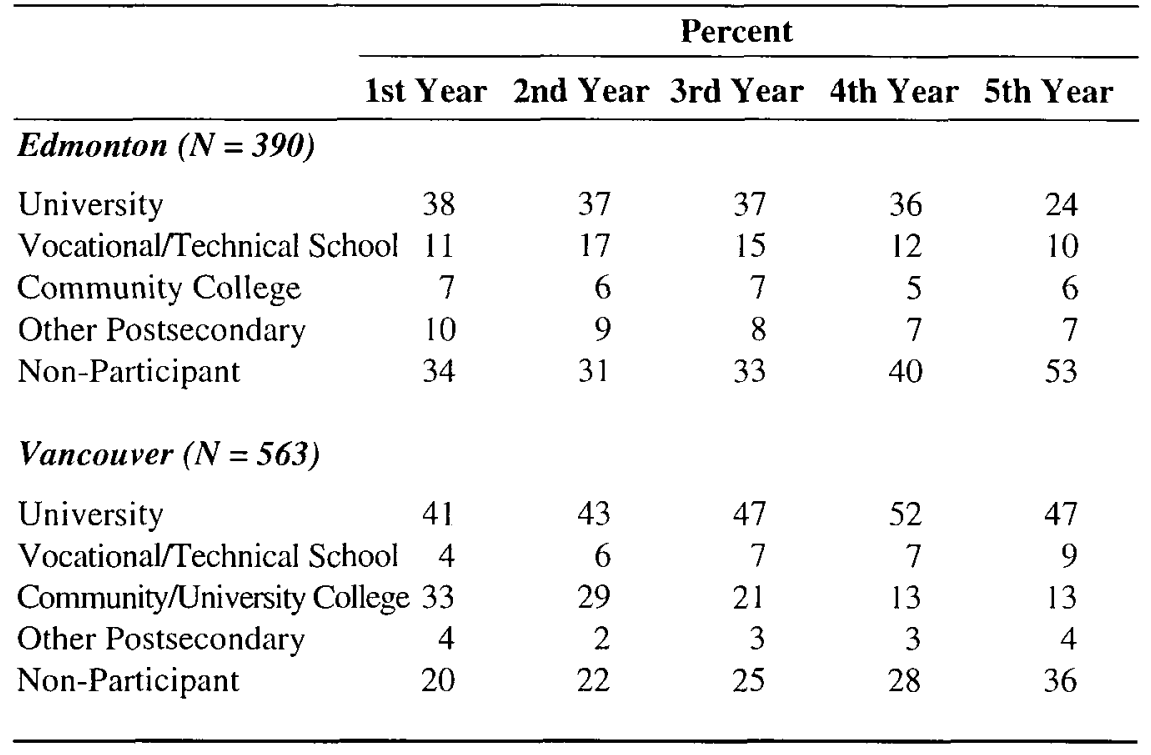

"other" postsecondary institutions was lower than that of Edmonton youth, ranging from 4 to $9 \%$ and 2 to $4 \%$, respectively. Non-participation directly following high school was considerably lower for Vancouver youth (20\% compared to $34 \%$ ). But, as in Edmonton, nonparticipation increased over time, rising to $36 \%$ by the fifth year of the study (compared to $53 \%$ of Edmonton youth).

Further analyses were conducted by gender, parental educational attainment, and type of program completed in high school (data not shown) ${ }^{8}$ For Edmonton youth, no substantive gender differences are evident in university participation patterns over the first four years. By 1990-91, more men than women remained in the university system. In contrast, more women attended community colleges and "other" postsecondary institutions, and more men studied at vocational/technical institutions. Non-participation patterns reveal that for the first two years, approximately equal proportions of women and men were not enrolled in the postsecondary system, but by $1987-88,38 \%$ of women compared 
with $28 \%$ of men were non-participants. Over the remaining two years, the size of the difference between the two groups did not change.

In the Vancouver sample, slightly more males than females enrolled in universities directly out of high school, and this difference persisted across all years of university participation. Similar to Edmonton youth, in each year between 1988-89 and 1993-94, more women than men attended community colleges and more than twice the proportion of men than women attended vocational/technical institutions. Except for the first year following high school, few gender differences are evident in participation in "other" forms of postsecondary education. Unlike the Edmonton pattern, gender differences in non-participation are less dramatic in Vancouver. Directly after high school, more males than females ( $23 \%$ versus $18 \%$ ) did not pursue postsecondary study, and in the following three years the gender difference was smaller.

When considering participation patterns by parental educational attainment, the patterns for Edmonton and Vancouver youth are very similar. Young people with university-educated parents were more likely to attend university, while non-participants and those attending vocational, technical, and "other" institutions tended come from families where neither parent had attended university. However, in both cities, parents' education appeared to have little impact on the probability of a young person attending community college.

The nature of the program completed in high school also appears to have influenced whether and where individuals participate in postsecondary education. Approximately half of Edmonton and Vancouver youth who had completed academic programs in high school entered directly into university. In Edmonton, much smaller proportions of the academic program graduates (between $8 \%$ and $10 \%$ ) began their studies at community colleges, vocational or technical institutions or "other" institutions. In Vancouver, $30 \%$ of youth who had completed academic programs in high school entered community colleges, and very few attended other forms of postsecondary education. Only $11 \%$ did not attend any postsecondary institution, compared with $24 \%$ of Edmonton youth.

Compared with Edmonton youth, fewer (38\% versus $63 \%$ ) individuals from non-academic high school programs in Vancouver did not engage in any form of postsecondary study directly out of high school. Also, they were more likely than Edmonton youth to attend university (15\% versus $6 \%$ ) and much more likely to enroll in community college 
( $40 \%$ versus $5 \%$ ). Postsecondary attendance by Edmonton youth was highest in vocational/technical $(16 \%)$ and "other" postsecondary institutions (10\%), compared with only 5\% of Vancouver youth. In Edmonton, except for Year 5, there was very little change in participation patterns by these two groups. In Vancouver, as the proportion of graduates from non-academic high school programs in the community college system declined over time (from $40 \%$ to $16 \%$ ), increases in both university enrolment (from $15 \%$ to about $25 \%$ ) and non-participation (from $38 \%$ to $53 \%$ ) were evident.

Thus, the Edmonton findings show much lower participation in the college system by graduates of both academic and non-academic high school programs. The Edmonton data also indicate a more static pattern of postsecondary participation (i.e., less apparent movement from one system into another) over the five-year period. In contrast, in Vancouver the community/university college system attracts a larger proportion of high school graduates and then appears to filter them, either out of the postsecondary system or into the university system. This pattern is observed for graduates of both academic and non-academic high school programs, but more so for the latter.

\section{Educational Credentials Earned}

In the remaining tables, we focus on the probability of respondents obtaining a postsecondary credential by the type of institution they attended in their first year following high school graduation. As indicated in the highlighted sections of Table 2 , in the years covered by this study, $74 \%$ of Edmonton youth who began their studies at university obtained a university degree. A small proportion of this group graduated from either community college or technical or vocational schools, and only $12 \%$ had not graduated from any institution. Graduation patterns of individuals who began at vocational or technical schools were similar; most $(80 \%)$ graduated from the same type of institution and the noncompletion rate was low. But only half of those commencing their studies at community colleges graduated with community college credentials (52\%); an additional $15 \%$ graduated from university and $11 \%$ from vocational or technical institutions. The non-completion rate of those who began community college studies in $1985-86$ was $22 \%$.

By 1993-94, 64\% of Vancouver youth who enrolled in university directly following high school had graduated from university. Except 
Table 2

\section{Educational Credentials Obtained by Institution Attended in First Year after Leaving High School by Gender; Edmonton (1985-1990) and Vancouver (1988-1993)}

\begin{tabular}{|c|c|c|c|c|}
\hline \multirow[b]{2}{*}{ Began Ist Year in: } & \multicolumn{4}{|c|}{ Credential Obtained (\%) } \\
\hline & $\begin{array}{c}\text { University } \\
\text { degree }\end{array}$ & $\begin{array}{l}\text { Technical } \\
\text { diploma }^{b}\end{array}$ & $\begin{array}{l}\text { College } \\
\text { diploma }\end{array}$ & $\begin{array}{l}\text { Did not } \\
\text { Graduate }\end{array}$ \\
\hline \multicolumn{5}{|l|}{ Edmonton $(N=390)$} \\
\hline $\begin{array}{l}\text { University } \\
\text { Female } \\
\text { Male }\end{array}$ & $\begin{array}{r}74 \\
78 \\
67\end{array}$ & $\begin{array}{r}7 \\
13\end{array}$ & $\begin{array}{l}6 \\
6\end{array}$ & $\begin{array}{l}10 \\
16\end{array}$ \\
\hline $\begin{array}{l}\text { Vocational/Technical School } \\
\text { Female } \\
\text { Male }\end{array}$ & $\begin{array}{rr}1 & 11 \\
& 17 \\
& 5\end{array}$ & $\begin{array}{r}80 \\
83 \\
76\end{array}$ & $\begin{array}{r}4 \\
10\end{array}$ & $\begin{array}{r}9 \\
14\end{array}$ \\
\hline $\begin{array}{l}\text { Community college } \\
\text { Female } \\
\text { Male }\end{array}$ & $\begin{array}{l}15 \\
14 \\
15\end{array}$ & $\begin{array}{r}7 \\
15\end{array}$ & $\begin{array}{r}52 \\
57 \\
46\end{array}$ & $\begin{array}{ll}22 & \\
21 \\
23\end{array}$ \\
\hline $\begin{array}{l}\text { TOTAL } \\
\text { Female } \\
\text { Male }\end{array}$ & $\begin{array}{ll}33 & \\
34 \\
31\end{array}$ & $\begin{array}{ll}25 & \\
& 20 \\
32\end{array}$ & $\begin{array}{r}14 \\
16 \\
11\end{array}$ & $\begin{array}{ll}31 & \\
34 \\
28\end{array}$ \\
\hline \multicolumn{5}{|l|}{ Vancouver $(N=563)$} \\
\hline $\begin{array}{l}\text { University } \\
\text { Female } \\
\text { Male }\end{array}$ & $\begin{array}{ll}64 & \\
69 \\
59\end{array}$ & $\begin{array}{c}1 \\
--\end{array}$ & $\begin{array}{l}2 \\
1\end{array}$ & $\begin{array}{l}33 \\
27 \\
40\end{array}$ \\
\hline $\begin{array}{l}\text { Vocational/Technical School } \\
\text { Female } \\
\text { Male }\end{array}$ & - & $\begin{array}{l}56 \\
50 \\
60\end{array}$ & -- & $\begin{array}{r}40 \\
50 \\
40\end{array}$ \\
\hline $\begin{array}{l}\text { Community/University college } \\
\text { Female } \\
\text { Male }\end{array}$ & $\begin{array}{ll}18 & \\
15 \\
20\end{array}$ & $\begin{array}{l}5 \\
4\end{array}$ & $\begin{array}{r}25 \\
30 \\
18\end{array}$ & $\begin{array}{r}51 \\
44 \\
58\end{array}$ \\
\hline $\begin{array}{l}\text { TOTAL } \\
\text { Female } \\
\text { Male }\end{array}$ & $\begin{array}{r}33 \\
33 \\
33\end{array}$ & $\begin{array}{l}8 \\
4\end{array}$ & $\begin{array}{r}7 \\
13\end{array}$ & $\begin{array}{l}47 \\
52 \\
43\end{array}$ \\
\hline \multicolumn{5}{|c|}{$\begin{array}{l}\text { In Vancouver, the question about credentials was asked in } 1993 \text {, and covered the pre- } \\
\text { vious five years. In Edmonton, questions about credentials were asked in 1992, and } \\
\text { covered the seven previous years. Thus, inter-city comparisons of levels of credential } \\
\text { attainment are not appropriate. } \\
\text { Includes apprenticeships. }\end{array}$} \\
\hline
\end{tabular}


for $3 \%$ who earned credentials elsewhere, the remainder $(33 \%)$ had not graduated from any type of postsecondary institution. Fifty-six percent of enrolees in vocational or technical institutions earned vocational or technical credentials, and the remainder did not complete their studies at any postsecondary institution. Postsecondary completion patterns by individuals who commenced their studies at community colleges differed from the other groups. By 1993-94, the majority (51\%) had not earned a postsecondary credential, $18 \%$ had graduated from a university, and only $25 \%$ had earned a community college certificate or diploma.

Table 2 also depicts postsecondary credentials earned by gender. Of the Edmonton youth commencing at university, more women $(78 \%)$ than men $(67 \%)$ completed university degrees. More men in this group either obtained technical or vocational credentials, or did not complete any postsecondary credential; only small proportion of women (10\%) who began their studies at university did not graduate from some institution. Of those who began in a vocational or technical institution, more women than men graduated with a vocational/technical diploma or certificate. Males in this category who did not earn technical or vocational credentials either completed community college studies or did not graduate at all. More women than men who began at community colleges obtained credentials from this type of institution. However, non-completion and university completion rates by gender were very similar in this group. Gender differences are accounted for primarily by more men earning technical or vocational credentials.

In Vancouver, of those commencing their studies at university, more women than men completed university degrees and more men did not complete any type of postsecondary credential. Of those who enrolled in vocational or technical studies in 1988-89, more men graduated from this type of institution, whereas women in this category were more likely not to finish their studies. More women (30\%) than men (18\%) who entered the community college system in 1988//89 earned community college credentials. However, men in this category were more likely than women to either graduate from university or not complete their studies.

Shifting our focus to the impact of family background, we see that among Edmonton youth who began in university, those with universityeducated parents were more likely to graduate from university (Table 3 ). Also, they were less likely not to have earned some type of postsecondary credential. This pattern holds for those who began their studies at vocational or technical institutions and community colleges. 
Table 3

Educational Credentials Obtaineda by Institution Attended in First Year after Leaving High School by Parents' Educational Attainment ${ }^{\text {b }}$ Edmonton (1985-1990) and Vancouver (1988-1993)

\begin{tabular}{|c|c|c|c|c|}
\hline \multirow[b]{2}{*}{ Began 1st Year in: } & \multicolumn{4}{|c|}{ Credential Obtained (\%) } \\
\hline & $\begin{array}{c}\text { University } \\
\text { degree }\end{array}$ & $\begin{array}{l}\text { Technical } \\
\text { diploma }\end{array}$ & $\begin{array}{l}\text { College } \\
\text { diploma }\end{array}$ & $\begin{array}{l}\text { Did not } \\
\text { Graduate }\end{array}$ \\
\hline \multicolumn{5}{|l|}{ Edmonton $(N=390)$} \\
\hline University & 74 & 10 & 6 & 12 \\
\hline Parent(s) graduated & 83 & 6 & 4 & 8 \\
\hline Both non-graduates & 64 & 13 & 8 & 16 \\
\hline Vocational/Technical School & 111 & 80 & 7 & 11 \\
\hline Parent(s) graduated & 20 & 82 & -- & 10 \\
\hline Both non-graduates & 9 & 70 & 9 & 12 \\
\hline Community college & 15 & 11 & 52 & 22 \\
\hline Parent(s) graduated & - & 17 & 67 & 17 \\
\hline Both non-graduates & 19 & 10 & 48 & 24 \\
\hline TOTAL & 33 & 25 & 14 & 31 \\
\hline Parent(s) graduated & 58 & 17 & 11 & 15 \\
\hline Both non-graduates & 22 & 29 & 15 & 38 \\
\hline
\end{tabular}

Vancouver $(N=563)$

University

64

Parent(s) graduated

Both non-graduates

Vocational/Technical School

Parent(s) graduated

Both non-graduates

Community/University college 18

Parent(s) graduated

Both non-graduates

TOTAL

Parent(s) graduated

Both non-graduates

a In Vancouver, the question about credentials was asked in 1993, and covered the previous five years. In Edmonton, questions about credentials were asked in 1992, and covered the seven previous years. Thus, inter-city comparisons of levels of credential attainment are not appropriate.

b Either or both parents have a university degree, as reported by their child. 
A similar trend is evident in postsecondary completion patterns of Vancouver youth. Except for those who began their studies at vocational or technical institutions, individuals with one or more parent with university credentials had lower rates of non-completion of postsecondary studies. Equal proportions of community college students with university educated parents graduated from community colleges and universities.

The type of high school program completed is also associated with degree completion status (Table 4). Regardless of postsecondary institution, those in the Edmonton sample who completed academic programs in high school were more likely than those who had completed non-academic programs to earn credentials from the same type of institution. Also, $18 \%$ of graduates from high school academic programs who began their studies in community colleges subsequently earned university degrees.

For Vancouver youth who began their studies at university, higher university completion rates and lower overall non-graduation rates were associated with completion of high school academic programs. Completion patterns of those beginning at vocational or technical institutions followed the opposite pattern. Students with high school academic credentials who entered directly into community colleges were less likely than their non-academic counterparts to graduate from community colleges $(21 \%$ versus $31 \%$ ). However, a further $21 \%$ of the academic group graduated from university, compared with only $11 \%$ from the nonacademic group. Hence, non-completion rates of community college students were higher among those who did not graduate from academic programs in high school.

\section{Joint Effects of Parental Education, High School Program, and Gender}

Thus far, we have examined the independent effects of three variables - gender, parental education, and high school program — on postsecondary participation directly out of high school and postsecondary completion status. Although the effect, or lack thereof, of each of these variables is interesting in and of itself, previous research indicates that these variables work together to constrain or facilitate postsecondary participation and completion. According to Bourdieu $(1977,1986)$, more educated parents transmit cultural capital in the form of habits or dispositions toward educational participation which, in turn results in higher academic attainments at the high school and postsecondary levels. Thus, 
Table 4

\section{Educational Credentials Obtained ${ }^{\mathrm{a}}$ by Institution Attended in First Year after Leaving High School by High School Program; Edmonton (1985-1990) and Vancouver (1988-1993)}

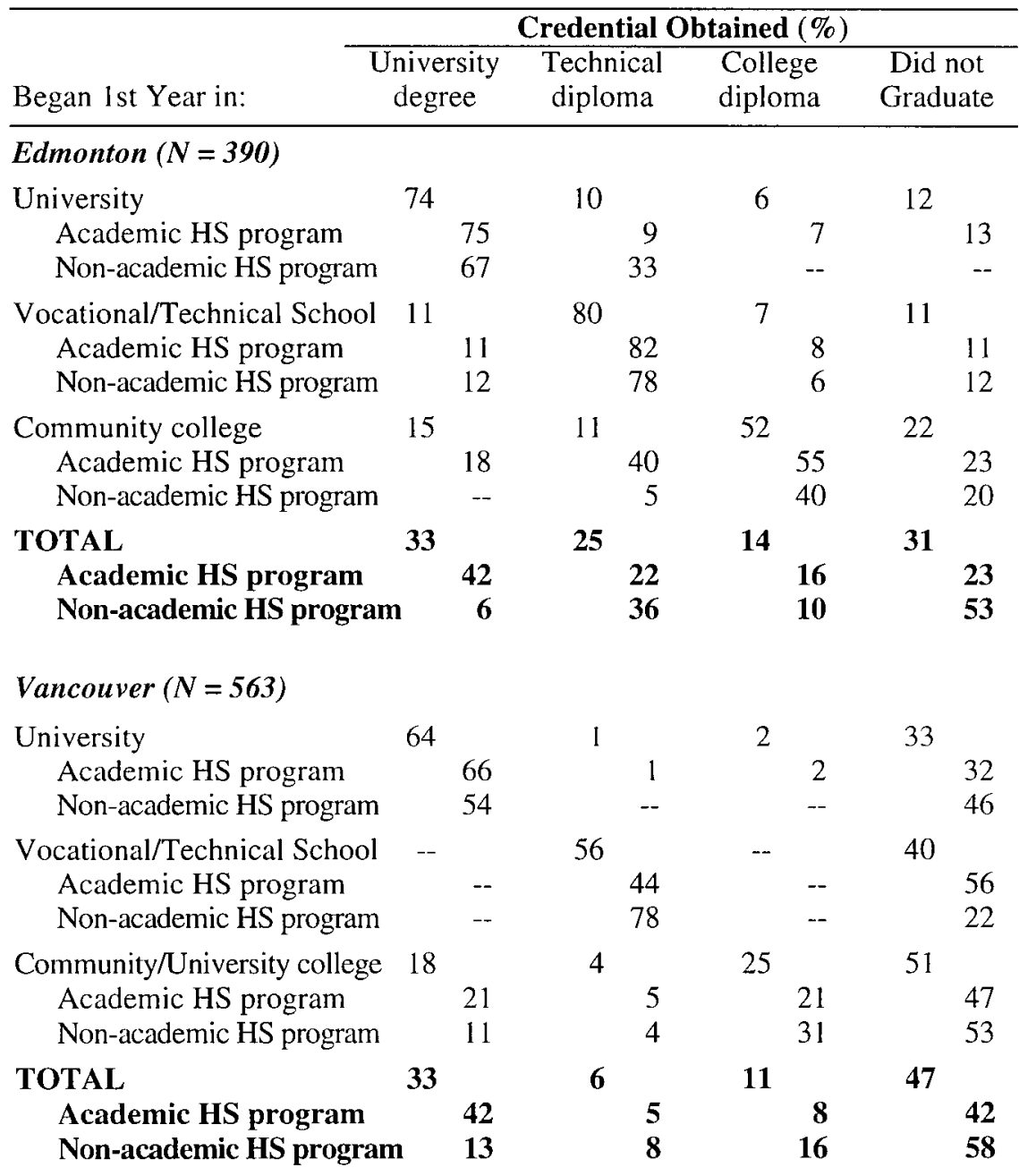

a In Vancouver, the question about credentials was asked in 1993, and covered the previous five years. In Edmonton, questions about credentials were asked in 1992, and covered the seven previous years. Thus, inter-city comparisons of levels of credential attainment are not appropriate. 
we should expect to find strong joint effects of educational background of parents and high school program on postsecondary participation and completion rates. McCall (1992) extends this theoretical perspective to include gender. She argues that gendered dispositions are another form of capital which add yet another dimension to the social class/attainment nexus.

To explore these interrelationships, we examine the joint effects of parental education, high school program, and gender on the attainment of postsecondary credentials. Table 5 indicates that, for respondents from both cities, although gender appears to have little effect on university or non-university completion, there is an interaction effect between parental education and high school program. That is, respondents who had completed academic programs in high school and were from university-educated families were much more likely than those with similar high school backgrounds but from non-university educated parents to have completed university. This pattern is consistent in both cities, although the differences are somewhat smaller in Vancouver $(52 \%$ versus $36 \%$ ) than Edmonton ( $62 \%$ versus $31 \%$ ).

Among students whose parents had not earned a university degree, the type of high school program completed also influenced the likelihood of university degree completion. In this group, approximately one third of Edmonton and Vancouver youth with academic credentials from high school had earned university degrees. However, only $3 \%$ of Edmonton respondents and $8 \%$ of Vancouver youth with similar (no university) family backgrounds and from non-academic high school programs completed university. Also, it is important to note that children from more educated families who began their postsecondary studies with non-academic high school credentials were equally as likely to complete a university degree as are those whose parents did not have university degrees but who had earned academic credentials in high school. This pattern is evident in both cities.

Regardless of parents' education, almost half of the Edmonton youth from non-academic high school programs acquired non-university credentials. Similar proportions of youth with academic high school credentials but non-university educated parents obtained other postsecondary credentials. One significant gender difference appears in the Edmonton sample - $62 \%$ of males from non-university families and non-academic high school programs obtained other postsecondary credentials, compared to 
University graduation by gender by high school program by parent(s) education

\begin{tabular}{|c|c|c|c|c|c|c|}
\hline & \multicolumn{3}{|c|}{ Edmonton } & \multicolumn{3}{|c|}{ Vancouver } \\
\hline & $(\mathbf{N})$ & $\begin{array}{c}\text { Percent } \\
\text { university } \\
\text { degree }\end{array}$ & $\begin{array}{l}\text { obtained } \\
\text { other } \\
\text { credential }\end{array}$ & $(\mathbf{N})$ & $\begin{array}{c}\text { Percent } \\
\text { university } \\
\text { degree }\end{array}$ & $\begin{array}{l}\text { obtained } \\
\text { other } \\
\text { credential }\end{array}$ \\
\hline TOTAL & $(390)$ & 33 & 38 & $(563)$ & 33 & 17 \\
\hline Parent(s) university-educated & $(115)$ & 58 & 28 & (194) & 48 & 13 \\
\hline Academic program & (104) & 62 & 26 & (154) & 52 & 11 \\
\hline Female & $(59)$ & 61 & 29 & $(88)$ & 50 & 16 \\
\hline Male & (45) & 63 & 22 & (66) & 54 & 5 \\
\hline Non-Academic program & $(11)^{*}$ & 27 & 45 & $(40)$ & 33 & 20 \\
\hline Female & $(9) *$ & 33 & 44 & (26) & 35 & 12 \\
\hline Male & $(2) *$ & -- & 50 & $(14) *$ & 29 & 36 \\
\hline Parent(s) not university-educated & $(275)$ & 17 & 43 & $(369)$ & 25 & 18 \\
\hline Academic program & $(182)$ & 31 & 42 & $(225)$ & 36 & 14 \\
\hline Female & $(101)$ & 34 & 41 & $(124)$ & 37 & 14 \\
\hline Male & $(81)$ & 28 & 44 & $(101)$ & 36 & 15 \\
\hline Non-Academic program & (93) & 3 & 43 & (144) & 8 & 25 \\
\hline Female & $(51)$ & 4 & 28 & $(82)$ & 9 & 27 \\
\hline Male & $(42)$ & 2 & 62 & $(62)$ & 7 & 23 \\
\hline
\end{tabular}

* Sub-sample size too small to provide reliable estimate. 
only $28 \%$ of females with similar backgrounds. This reflects the low enrolment of females in vocational institutions noted earlier. In Vancouver, the odds of earning non-university credentials were highest for those from non-academic high school programs. Again, this does not appear to be influenced by parental educational levels.

Edmonton youth from university educated families were twice as likely as their Vancouver counterparts to earn non-university credentials. This pattern holds for graduates of academic and non-academic high school programs. In all categories, considerably fewer Vancouver respondents completed non-university programs. Only $14 \%$ of Vancouver respondents with academic credentials from high school but from non-university educated families have completed a non-university credential. The comparable proportion of Edmonton youth is $42 \%$.

\section{DISCUSSION AND CONCLUSION}

Our panel data from Vancouver and Edmonton document considerable diversity in the postsecondary educational activity of cohorts of high school graduates exposed to an articulated postsecondary system. Rather than reviewing all of our findings, we will discuss only the more central results, organizing our comments around the core questions that frame this paper. Although we acknowledge that our small samples and some methodological differences between the two studies require us to draw cautious conclusions, we nevertheless believe that these survey results can be very useful in assessing the effects of class and gender within articulated postsecondary education systems.

We also realize that both the British Columbia and Alberta systems have changed, to some extent, since our data were collected. By the mid1990s, British Columbia had expanded its degree granting structure through further development of the university college system and by affording degree granting status to the British Columbia Institute of Technology and Emily Carr College of Art and Design (Dennison, 1997). Alberta's system now includes four degree-granting private colleges (Andrews, Holdaway, \& Mowat, 1997). In Edmonton, the University of Alberta accepts up to a maximum of two years of transfer credit from specified courses and programs offered by designated institutions in the province, including Grant MacEwan College, Concordia College, and the King's University College. This, of course, does not invalidate our findings. On-going evaluations of contemporary postsecondary systems, and 
attempts to re-structure them further, can still benefit from careful examinations of how the system operated at the time of our study.

This study reveals larger proportions of youth choosing to attend university over other postsecondary institutions in both cities, reflecting the patterns of postsecondary education in Canada over the past several decades. In Edmonton, participation tailed off after four years, no doubt because most of those entering the university system had graduated by then. In Vancouver, university attendance increased slightly towards the end of the five-year period. This difference might reflect a somewhat larger proportion of Vancouver youth who transferred into the university system after beginning a program elsewhere. In addition, the local labour market had become less inviting by the early 1990s, perhaps encouraging some Vancouver youth to stay in school longer. This would also explain the lower non-participation rate in the Vancouver sample.

However, we should probably not attribute too much influence to the labour market since, even though the unemployment rates were higher in Edmonton than in Vancouver at the outset of the study, the non-participation rate was also higher in this city at that time. This difference might then be attributed to the greater number of postsecondary choices available to Vancouver students. More specifically, the greater range of community and university colleges in Vancouver would account for the much higher participation level in these types of institutions in that city. In contrast, technical school attendance was somewhat higher in Edmonton. This might simply mean that some youth chose to attend a vocational school because of fewer college openings. However, in part, it might also reflect the impact of Alberta's resource-based economy. Technical institutions offer programs leading directly to employment in the energy industry, for example, and Alberta has a more fully-developed apprenticeship system that is based within the technical/vocational postsecondary system.

Our findings reveal some fairly distinct gender differences. In general, vocational and technical schools continue to be favoured by young men, in both cities. Gender differences in entry into the college system are not as distinct, but we see some evidence of women remaining longer in this system. In contrast, men appear to remain longer in the university system. The latter finding may mean more men are continuing on into post-graduate university programs, a pattern observed in other studies using aggregate data (Statistics Canada, 1994). 
Differences in postsecondary participation by socio-economic background are pronounced in this study. Young people with university-educated parents are much more likely to continue their education after high school, particularly in the university system, and are also more likely to complete their postsecondary programs. The Edmonton-Vancouver comparisons of participation rates suggest a larger "class" difference in Edmonton. Perhaps the greater availability of postsecondary options in Vancouver explains this difference. If so, we would have to conclude that more articulated postsecondary systems lead more youth from a broader range of social backgrounds to enter and complete postsecondary programs. That said, the "class" differences in Vancouver are still large. Even with a system providing as many participation and transfer options as this one, there is still considerable evidence of the inter-generational transfer of advantage.

The effects of family background appear to be mediated by the high school program completed by respondents in our studies. In other words, graduates of "academic" high school programs are much more likely to continue their education after high school, most often in university, and they are also more likely to complete their programs. In Vancouver, nonacademic program graduates, if they continue their education, are more likely to attend community colleges. In Edmonton, a larger proportion of this group enter the technical school system.

Compared to Vancouver, the Edmonton data reveal higher completion rates for youth who entered university, the technical/vocational system, and the college system. Some of this difference might be due to differences in research design (see Appendix), since Edmonton subjects had a somewhat longer time in which they might have acquired a particular credential. However, it is also possible that one of the consequences of a postsecondary system (in Vancouver) that allows more students to enter is that a smaller proportion manage to complete their programs. Our data also reveal a finding observed in other studies, namely, higher completion rates among women in the community college system.

In summary, family background continues to strongly influence postsecondary educational outcomes. To the extent that the Vancouver system was a more fully-articulated system in 1988 (compared to Edmonton in 1985), the opening up of participation and transfer options does appear to have a positive effect. Even so, large "class" differences in participation and completion remain. Gender also continues to matter, 
but in more subtle ways than in the past when men were simply more likely to continue their education past high school. Moreover, it is clear that the pattern whereby social class advantages are passed from one generation to the next continue to begin within the high school system, since high school program is a strong predictor of postsecondary participation and completion. So what are the key policy implications of our findings?

First, it is imperative to continue to monitor the extent to which each provincial postsecondary system provides opportunities for access and program completion. The structure of each system dictates the availability of offerings. However, social, cultural, and economic forces have a major effect on how individuals gain access to the system. In other words, we must differentiate between availability and accessibility. That is, while acknowledging the benefits of expanding the number and type of postsecondary seats available to students, we must continue to watch for structural barriers to postsecondary participation (e.g., low socio-economic status) and for changes to postsecondary access systems (such as increased tuition fees) that can limit entry to and completion of postsecondary studies.

This analysis was limited to participation and degree completion patterns of urban youth in two articulated provincial systems. As we stated earlier, the Alberta and British Columbia systems were explicitly designed to promote "access for all" and through sophisticated articulation arrangements, to enhance a seamless passage among the various levels and forms of postsecondary offerings. Comparisons with non-articulated provincial systems such as those found in Ontario and Nova Scotia, and analyses of urban and rural samples, would further clarify how various postsecondary systems enhance or hinder postsecondary participation.

It is not enough, however, to monitor the postsecondary system in isolation. Clearly, students who graduate from academic programs in high school are more successful than their non-academic peers in accessing and completing postsecondary studies. Although students in Alberta and British Columbia participate in secondary systems that are not overtly tracked or streamed, they must complete certain requirements to gain university admission. Hence, long term planning strategies must be employed by university-bound youth. It remains unclear, however, why such high proportions of "non-academic" high school students, particularly in Alberta, do not take advantage of the less rigid entrance requirements of community colleges and other non-university institutions. 
The transmission of cultural and social capital of parents to their children has been well documented in the literature (Andres, 1993; Bourdieu, 1986; de Broucker \& Lavallée, 1998; Lareau, 1987; Looker, 1997). This study has demonstrated that despite efforts to minimize barriers to participation, transfer, and degree completion for disadvantaged groups, these forms of parental capital continue to be translated into advantages for children of culturally advantaged families. Again, we may turn to the secondary system to determine whether counsellors and teachers could play a greater role in enriching the social and cultural capital for less advantaged youth.

Finally, the greater success of women within some parts of the postsecondary system warrants further investigation. Community colleges, with their reputation as "student friendly" institutions may attract and retain more women. However, the greater proportion of women still participating in the college system in the last years of the study requires further study. In particular, transfer patterns should be closely monitored. Compared to the past, women are now more likely than men to earn bachelor's degrees (Andres \& Guppy, 1991; Statistics Canada, 1994). However, higher proportions of men complete graduate programs. In depth comparative studies of women's and men's experiences and strategies for success within various postsecondary programs would illuminate the dynamics of postsecondary participation and completion patterns at the graduate level.

\section{Reference List}

Alba, R.D., \& Lavin, D.E. (1981). Community colleges and tracking in higher education. Sociology of Education, 54(4), 223-237.

Alberta Advanced Education. (1984). Participation patterns study. Report of the committee to examine participation trends of Alberta postsecondary students. Edmonton, AB: Alberta Advanced Education, Planning Secretariat.

Alberta Council on Admissions and Transfer. (1994). Alberta transfer guide 1994-95. Edmonton, AB: Author.

Alexander, K., Holupka, S., \& Pallas, A.M. (1987). Social background and academic determinants of two-year versus four-year college attendance: Evidence from two cohorts a decade apart. American Journal of Education, 96(1), 56-80. 
Anderson, K.L. (1984). Institutional differences in college effects. Boca Raton, FL: Florida Atlantic University. (ERIC No. ED 256 204).

Andres, L. (1995). Class of 1988. Grade 12 follow-up five years later. Research report for the British Columbia Council on Admissions and Transfer.

Andres, L. (1993). Life trajectories, action, and negotiating the transition from high school. In P. Anisef \& P. Axelrod (Eds.), Transitions, schooling, and employment in Canada (pp. 137-157). Toronto, ON: Thompson Educational Publishing, Inc.

Andres, L., \& Dawson, J. (1998). Phase III. A history of transfer policy and practice in British Columbia. Vancouver, BC: British Columbia Council on Admissions and Transfer.

Andres, L., \& Guppy, N. (1991). Opportunities and obstacles for women in higher education. In J.S. Gaskell \& A. McLaren (Eds.), Women and education (2nd ed.), (pp. 163-192). Calgary, AB: Detselig Press.

Andres, L., \& Looker, E.D. (1997). Capital and community: Educational expectations, attendance, and attainment of rural and urban youth. Paper presented at the 1997 meeting of the Rural Sociological Society, Toronto, ON. Andrews, M., Holdaway, E., \& Mowat, G. (1997). Postsecondary education in Alberta since 1945. In G. Jones (Ed.), Higher education in Canada: different systems, different perspectives, (pp. 59-92). New York, NY: Garland Publishing.

Anisef, P. (1985). Accessibility to postsecondary education in Canada: A review of the literature. Ottawa, ON: Department of the Secretary of State of Canada.

Astin, A. (1982). Minorities in American higher education. San Francisco, CA: Jossey-Bass.

Berghofer, D., \& Vladicka, A. (1980). Access to opportunity 1905-80. Edmonton, AB: Alberta Advanced Education and Manpower.

Bourdieu, P. (1977). Outline of a theory of practice (R. Nice, Trans.). Cambridge: Cambridge University Press. (Original work published in 1972).

Bourdieu, P. (1986). The forms of capital (R. Nice, Trans.). In J.C. Richardson (Ed.), Handbook of theory and research for the sociology of education, (pp. 241-258). New York, NY: Greenwood Press. (Original work published in 1973).

Bourdieu, P., \& Passeron, J. (1979). The inheritors (R. Nice, Trans.). Chicago, IL: University of Chicago Press. (Original work published in 1966).

Brint, S. \& Karabel, J. (1989). The diverted dream. Community colleges and the promise of educational opportunity in America, 1900-1985. New York, NY: Oxford University Press. 
Clark, B. (1960). The 'cooling-out' function in higher education. In A.H. Halsey, J. Floud, \& C.A. Anderson (Eds.), Education, economy, and society, (pp. 513-523). New York, NY: The Free Press.

de Broucker, P., \& Lavallée, L. (1998). Getting ahead in life. Does your parents' income count? Canadian Social Trends, Summer, 6-10.

Dennison, J. (1997). Postsecondary education in Alberta since 1945. In G. Jones (Ed.), Issues in Canadian Higher Education, (pp. 31-57). New York, NY: Garamond Press.

Dennison, J.D., \& Gallagher, P. (1986). Canada's community colleges. A critical analysis. Vancouver, BC: University of British Columbia Press.

Dennison, J., \& Jones, G. (1970). The community college transfer student at the University of British Columbia - a three year study. Vancouver, BC: Vancouver City College.

Department of the Secretary of State of Canada. (1988). Access to excellence. Being Canadian... Working together for postsecondary education. Ottawa, ON: Minister of Supply and Services.

Department of the Secretary of State of Canada. (1990). Federal and provincial support for postsecondary education in Canada 1988-89. Ottawa, ON: Minister of Supply and Services.

Fortin, M. (1987) Accessibility to and participation in the postsecondary education system in Canada. Saskatoon, SK: National Forum on Postsecondary Education.

Guppy, N. (1984). Access to higher education in Canada. Canadian Journal of Higher Education, 14(3), 79-93.

Guppy, N., \& Pendakur, K. (1989). The effects of gender and parental education on participation within postsecondary education in the 1970s and 1980s. Canadian Journal of Higher Education, 19(1), 49-62.

Jeffels, R.R. (1972). College and university: Towards the first decade. Occasional Paper No. 1, Postsecondary Education, British Columbia Department of Education.

Jones, G. (1997). (Ed.). Higher education in Canada: Different systems, different perspectives. New York, NY: Garland Publishing.

Karabel, J. (1986). Community colleges and social stratification in the 1980s. In L.S. Zwerling (Ed.), The community college and its critics. New Directions for Community Colleges, 54(2), 13-30.

Krahn, H., \& Mosher, C. (1992). The transition from school to work in three Canadian cities, 1985-89: Research design and methodological issues. Edmonton, AB: Population Research Laboratory. University of Alberta.

Lareau, A. (1987). Social class differences in family-school relationships: The importance of cultural capital. Sociology of Education. 60(1), 73-85. 
Looker, E.D. (1997). In search of credentials: Factors affecting young adults' participation in postsecondary education. Canadian Journal of Higher Education, 27(2, 3), 1-36.

Macdonald, J.B. (1962). Higher education in British Columbia and a plan for the future. Vancouver, BC: University of British Columbia.

McCall, L. (1992). Does gender fit? Bourdieu, feminism, and the conceptions of social order. Theory and Society, 26(6), 837-879.

Medsker, L. \& Tillery, D. (1971). Breaking the access barrier. New York, NY: McGraw Hill.

Ministry of Advanced Education and Job Training. (1988). B.C. postsecondary enrolment statistics 1987/88. Victoria, BC: Funding and Analysis Division.

Ministry of Education \& Training (1996). Excellence, accessibility, responsibility. Report of the Advisory Panel on Future Directions for postsecondary Education. Ontario: Ministry of Education \& Training.

O'Neill, G.P. (1981). Postsecondary aspirations of high school seniors from different socio-demographic contexts. Canadian Journal of Higher Education, /1(2), 49-66.

Pincus, F. (1986). Vocational education: More false promises. In L.S. Zwerling (Ed.), The community college and its critics. New Directions for Community Colleges, 54(2), 41-52.

Porter, M., \& Jasmin, G. (1987). A profile of postsecondary students in Canada. Ottawa, ON: Secretary of State and Statistics Canada.

Report of the Provincial Access Committee. (1988). Access to advanced education and job training in British Columbia. British Columbia: Ministry of Advanced Education and Job Training.

Report of the Royal Commission on the Economic Union and Development Prospects of Canada. (1983). Ottawa, ON: Information Canada.

Standing Senate Committee on National Finance. (1987). Federal policy on postsecondary education. Ottawa, ON: Minister of Supply and Services Canada.

Statistics Canada. (1994). Education in Canada 1992-93. Ottawa, ON: Statistics Canada (cat. no. 81-229).

Tinto, V. (1975). The distributive effects of public junior college availability. Research in Higher Education, 3(3), 261-274.

Velez, W. (1985). Finishing college: The effects of college type. Sociology of Education, 58(3), 191-200. 


\section{Appendix: Methodological Issues}

While the Edmonton and Vancouver panel surveys were very similar in terms of research questions asked and variables measured, several differences should be noted. In addition, since sample attrition is always an issue in longitudinal studies, the implications of a significant number of respondents dropping out of each panel study need to be considered.

\section{Differing Labour Market Contexts}

In Edmonton, the (annual average) unemployment rate was 12\% in 1985, but labour market conditions improved throughout the five years covered by this study. By 1990, the unemployment rate had fallen to $7.8 \%$. In contrast, Vancouver unemployment rates declined during the first two years of the study (from $9.4 \%$ in 1988 to $7.1 \%$ in 1990) and then rose again to $9.3 \%$ by 1993 .

To the extent that unemployment rates influence postsecondary decisions of youth (a weak labour market might encourage more individuals to stay in school), these different patterns might lead to us to expect higher levels of postsecondary activity at the outset of the study in Edmonton, compared to Vancouver. The improving labour market in Edmonton might also encourage some youth to leave school before acquiring a degree or diploma. In contrast, in Vancouver, declining labour market opportunities might encourage more youth to return to postsecondary education after some time away from school, or more to stay in college or university for a longer time. Although not central to our research questions, these labour market factors need to be kept in mind when comparing results from the two different panel studies.

\section{Sample Attrition}

Patterns of sample attrition in the Vancouver and Edmonton samples were very similar. Male subjects were somewhat more likely to drop out of the study as the years passed, as were those less academically-oriented (e.g., lower grades in high school, less self-reported interest in schooling, lower educational aspirations). The fact that young women were more likely to remain in the study reinforced the importance of systematically examining gender differences throughout the study. While we obviously have a substantive interest in comparing postsecondary participation patterns among male and female high school graduates, we also want to ensure that our generalizations about total-sample patterns in each city are not being biased by a gendered pattern of attrition.

The lower level of sample attrition among more academically-oriented youth means that any conclusions we draw about the "openness" of the postsecondary systems in the two provinces may, in fact, be over-estimates. In other words, if all of the original sample members had remained in the study, we 
expect that we would have observed a slightly lower level of postsecondary participation. Also, to the extent that less academically-oriented high school students might choose college and technical school programs over university programs, our results probably under-estimate participation patterns in the former types of institution.

\section{Measurement Differences}

The Vancouver panel study included only young people who had graduated from high school $(\mathrm{n}=563)$. In contrast, the Edmonton study surveyed students in grade 12 at the end of the academic year. Some of these students did not complete all of the requirements needed for graduation and returned to high school the following year. Furthermore, during the mid-1980s in Alberta, a pattern of twelfth-grade students returning for an extra year or half-year of high school (to raise their marks, to participate in athletics, or for other reasons) became quite common. In fact, $27 \%$ of the Edmonton subjects had returned to high school in 1986. A year later, 6\% were still in the high school system. In order to maintain the sample size and not exclude "slower finishing" students from the analysis, the educational activities of Edmonton students who completed high school in 1986 were tracked from 1986 to 1991. The few who left high school in 1987 were tracked until 1992. Then, in the five-year longitudinal analysis, all three groups (those who graduated in 1985, 1986, and 1987) are treated similarly, as if they all graduated in 1985. Even so, a small number of the Edmonton subjects $(n=14)$ never did obtain a high school diploma. Consequently, the final Edmonton sample contains 390 respondents.

While the complete Edmonton panel study spans seven years (1985 to 1992), only the educational activity (type of institution attended) of respondents between 1985 and 1990 is examined in this paper. However, a question about acquisition of degrees and diplomas was only asked in the 1992 survey and it did not specify the year in which the credential had been obtained. Even though the data strongly suggest that most Edmonton respondents acquired their credentials in the first five years after high school, the time-period in which they might have received a degree or diploma was actually longer ( 7 years) than was the case for the Vancouver respondents ( 5 years). Thus, evidence of higher proportions of Edmonton youth receiving credentials (compared to Vancouver) must still be interpreted cautiously. 


\section{Notes}

1 The path to university within the Quebec postsecondary system requires participation in the CEGEP system. Because of this difference, the Quebec system cannot be easily compared with other articulated systems in Canada.

2 Two other private colleges (Augustana University College and Canadian Union College), both outside the normal commuting distance for Edmonton students, also received the right to award undergraduate degrees in specific program areas.

3 Some of the material in this section is drawn from Andres and Dawson (1998).

4 This figure includes university transfer, career/technical, general studies, and college preparatory programs.

5 Respondents from the following school districts were included in the Vancouver sample: Langley, Surrey, Delta, Richmond, Vancouver, New Westminster, Burnaby, Maple-Ridge-Pitt Meadows, Coquitlam, North Vancouver, West Vancouver.

6 In Edmonton, the few subjects who participated in more than one institution in a given year are classified according to where they spent most time. Because of how the question was asked in the Vancouver study, we cannot identify the "main" institution for those who attended more than one. Hence, the totals for Vancouver youth in Tables 1 through 4 may exceed 100\%.

7 It is possible that some of the participants in "other" postsecondary institutions were attending local private colleges (Kings or Concordia), but did not place themselves in the "community college" category.

8 Detailed tables of postsecondary activity by gender, parental educational attainment, and type of program completed in high school are available upon request. 